\title{
Shortening tends to increase aortic foam cell count and wall thickness in male Wistar rats
}

\author{
Rokhima Lusiantari*, Miranti Dewi Pramaningtyas*, Titis Nurmasitoh*, \\ Rachmi Hidayati Pattimura*, and Anggita Dewanti*
}

\begin{abstract}
\section{BACKGROUND}

Shortening is widely used as raw material for bread and other foods. Hypercholesterolemia increases aortic arch foam cell formation and abdominal aortic wall thickness. This study aimed to determine the effect of shortening on the number of aortic arch foam cells and abdominal aortic wall thickness in rats.
\end{abstract}

\section{METHODS}

This study was of experimental posttest control group design. Twenty four male Wistar rats were randomized into 4 groups. The negative control group $(\mathrm{C}-)$ received standard feed, the positive control group $\left(\mathrm{C}_{+}\right)$standard high-fat feed, group $T_{1}$ shortening and standard feed at a ratio of 1:5 and group $\mathrm{T}_{2}$ shortening and standard feed at a ratio of 1:10. The interventions were given for 6 weeks through gavage. The foam cell count in the aortic arch and the thickness of the abdominal aortic wall were measured. Oneway ANOVA test was used to analyze the data.

\section{RESULTS}

There was no significant difference in the mean foam cell count of the aortic arch between the four groups $\mathrm{C}-(7.17 \pm 4.17), \mathrm{C}_{+}(9.33 \pm 7.01), \mathrm{T}_{1}$ $(11.83 \pm 4.88)$ and $T_{2}(9.33 \pm 6.80)(p=0.598)$. The mean thickness of the abdominal aortic wall between the four groups $\mathrm{C}-(741.98 \pm 60.67 \mu \mathrm{m}), \mathrm{C}_{+}$ $(714.29 \pm 90.59 \mu \mathrm{m}), \mathrm{T}_{1}(838.90 \pm 75.86 \mu \mathrm{m})$, and $\mathrm{T}_{2}(749.88 \pm 99.37 \mu \mathrm{m})$ also was not significantly different $(\mathrm{p}=0.110)$.

\section{CONCLUSION}

Shortening tends to increase the foam cell count of the aortic arch and the thickness of the abdominal aortic wall of rats.

Keywords: Shortening, histopathology, aortic arch, abdominal aorta, rats
*Department of Physiology

Faculty of Medicine

University of Islam Indonesia

\section{Correspondence:}

Rokhima Lusiantari Department of Physiology

Faculty of Medicine University of Islam Indonesia Jl. Kaliurang Km. 14.5 Ngemplaques, Sleman, Yogyakarta 55584 Mobile: +62813 91612612 rokhimalusi@uii.ac.id

Date of first submission, June 12, 2017 Date of final revised submission,

February 12, 2018

Date of acceptance, February 15, 2018

This open access article is distributed under a Creative Commons AttributionNon Commercial-Share Alike 4.0

International License

Cite this article as: Lusiantari R, Pramaningtyas MD, Nurmasitoh T, Pattimura RH, Dewanti A. Shortening tends to increase aortic foam cell count and wall thickness in male Wistar rats. Univ Med 2018;37:13-8. doi: 10.18051 /UnivMed.2018.v37.13-18 


\section{INTRODUCTION}

Cardiovascular disease is one of the causes of mortality and disability in cases of noncommunicable disease (NCD) in various countries..$^{(1,2)}$ Non-communicable disease, such as cardiovascular disease, is a main problem not only in developed countries but also in developing countries. In 2014, Russia and the US had the highest mortality rates from ischemic heart disease. ${ }^{(3)}$ According to the Global Status Report on Non-communicable Disease, in 2008 more than 36 million persons died (63\% of total mortality) as a result of non-communicable disease in countries with lower to middle per capita incomes. ${ }^{(4)}$ Cardiovascular disease may be caused by a number of factors, one of them being hyperlipidemia that may occur as a result of consumption of a high fat diet. ${ }^{(5)}$

Hypercholesterolemia is a condition characterized by a high cholesterol concentration in the blood. Hypercholesterolemia may cause the accumulation of fat and oxidized low density lipoprotein (LDL) cholesterol in blood vessel walls, ${ }^{(6)}$ leading to the formation of plaques in the blood vessels and the occurrence of ischemic heart disease. Hypercholesterolemia may also increase oxidative stress in various organs, such as the liver, heart, and kidneys. ${ }^{(6-8)}$

Several studies on animal models of hypercholesterolemia have been conducted, in which the condition was induced by means of intravenous adrenalin, duck egg yolk, and lard. However, these studies yielded less significant and consistent results in causing hypercholesterolemia in rats. In addition, the use of lard is constrained by ethical considerations, while cost is also a problem with standard high fat feeds. ${ }^{(9,10)}$ In this connection, shortening may also be used as inducer of hypercholesterolemia, since it is of relatively low cost and easily available. ${ }^{(11)}$

Fat is widely used as raw material of bread and other foods. ${ }^{(12,13)}$ According to Nurmasitoh and Pramaningtyas, shortening may increase total cholesterol concentration, triglycerides and LDL in the blood of male Wistar rats. ${ }^{(11)}$ Shortening, which is made by hydrogenation, has a high trans fat content. ${ }^{(12,13)}$ Trans fat increases the LDL concentration and decreases the high density lipoprotein (HDL) concentration in the blood, so increasing the risk for atherosclerosis. Oxidized LDL may induce the formation of atherosclerotic plaques that ultimately lead to cardiovascular disorders, one of them being acute coronary syndrome. Hypercholesterolemia may promote the formation of atherosclerotic lesions, the onset of which is marked by an increase in foam cell count. Hypercholesterolemia may also cause an increase in the thickness of blood vessel walls. ${ }^{(6,14,15)}$

To date there are still few studies on the effect of shortening on foam cells and aortic wall thickness. Therefore the purpose of the present study was to evaluate the effects of stepped doses of shortening on foam cell count and abdominal aortic wall thickness in male Wistar rats.

\section{METHODS}

\section{Study design}

This was an experimental post-test only controlled study, that was conducted in the Physiology Laboratory and the Integrated Research Laboratory, Faculty of Medicine, Universitas Islam Indonesia, from May to December 2016.

\section{Animals and experimental procedure}

The study involved 24 male Wistar rats aged 2-3 months and weighing 200-250 grams that were obtained from the Integrated Research and Testing Laboratory (LPPT) Gadjah Mada University. The sample size was calculated using the Federer formula $(\mathrm{n}-1)(\mathrm{t}-1) \geq 15$, where $\mathrm{n}=$ sample size for each intervention and $\mathrm{p}=$ number of interventions. Previous to the intervention, the rats were adapted for 7 days. The rats were put in cages of $40 \mathrm{~cm} \times 20 \mathrm{~cm}$ x $20 \mathrm{~cm}$ and subjected to 12-hour light and dark cycles. The rats were randomly divided into 4 groups, i.e. a negative control group (C-), a 
positive control group $\left(\mathrm{C}_{+}\right)$and two intervention groups $\left(T_{1}\right.$ and $\left.T_{2}\right)$. Group $C$ - received AD II standard rat feed containing $51 \%$ carbohydrates, $15 \%$ crude protein, $3-7 \%$ crude fat, $6 \%$ crude fiber, $7 \%$ ash, $0.9-11 \%$ calcium, $0.6-0.9 \%$ phosphor, $12 \%$ water, antibiotics, and a coccidiostat. Group $\mathrm{C}_{+}$received standard high fat feed, while groups $T_{1}$ and $T_{2}$ received shortening and standard feed at a ratio of 1:5 and 1:10, respectively. The intervention was administered via the oral route by gavage for 6 weeks in the Physiology Laboratory. Upon completion of the intervention, the animals were terminated.

\section{Prepration of histological slides}

After the rats were terminated, their aortic arch and abdominal aorta were removed, fixed in formalin for 2 days, dehydrated in alcohol $70 \%$, and transported to the Integrated Research Laboratory, Faculty of Medicine, Universitas Islam Indonesia, where they were made into histological slides. The aortic arch and abdominal aorta of each rat were block paraffinized, microtomed, and stained with hematoxylin-eosin (HE). The histological slides were evaluated with respect to foam cell count, using an Olympus CX41 binocular microscope connected to an Optilab camera, with which images were taken of 10 fields of view at 40x magnification. The foam cell count was counted using a cell count application. The foam cells that were counted were those located in the tunica intima and tunica media. The thickness of the abdominal aortic wall was measured from the lamina intima up to the lamina media in 8 fields of view in a clockwise direction (at 12.00, 13.30, 15.00,
$16.30,18.00,19.30,21.00,22.30)$ using Optilab and micrometer scale. ${ }^{(10)}$

\section{Data analysis}

The test used was one-way Anova, with the level of significance set at $p<0.05$, followed by a post-hoc Tukey test to determine betweengroup differences. ${ }^{(16)}$

\section{Ethical clearance}

The present study obtained ethical clearance from the Ethics Committee Faculty of Medicine Universitas Islam Indonesia under no. 03/Ka.Kom.Et/70/KE/II/2016.

\section{RESULTS}

The results of the present study shows that the greatest increase in foam cell count was in the intervention group $T_{1}$ receiving the combination of shortening and standard feed at the ratio of 1:5, followed by groups $\mathrm{C}_{+}, \mathrm{T}_{2}$ and $\mathrm{C}$ (Figure 1). Although $\mathrm{T}_{1}$ had the greatest increase in foam cell count as compared to group C-, the results of the statistical analysis were still not significant $(\mathrm{p}=0.598)$.

In agreement with the increase in foam cell count, the greatest abdominal aortic wall thickness was in intervention group $\mathrm{T}_{1}$, followed by groups $\mathrm{T}_{2}, \mathrm{C}$, and $\mathrm{C}_{+}$(Figure 2 ).

Although $\mathrm{T}_{1}$ had increased abdominal aortic wall thickness as compared to group C-, the results of the statistical analysis were not yet significant $(\mathrm{p}=0.110)$. The complete set of data on mean aortic arch foam cell count and abdominal aortic wall thickness is shown in Table 1.

Table 1. Mean aortic arch foam cell count and abdominal aortic wall thickness by intervention group

\begin{tabular}{|c|c|c|c|c|c|}
\hline \multirow{2}{*}{ Variable } & \multicolumn{4}{|c|}{ Intervention group } & \multirow{2}{*}{ p value } \\
\hline & $C_{-}(n=6)$ & $C_{+}(n=6)$ & $T_{1}(n=6)$ & $T_{2}(n=6)$ & \\
\hline Foam cell count & $7.17 \pm 4.17$ & $9.33 \pm 7.01$ & $11.83 \pm 4.88$ & $9.33 \pm 6.80$ & 0.598 \\
\hline Aortic wall thickness $(\mu \mathrm{m})$ & $741.98 \pm 60.67$ & $714.29 \pm 90.59$ & $838.90 \pm 75.86$ & $749.88 \pm 99.37$ & 0.110 \\
\hline
\end{tabular}



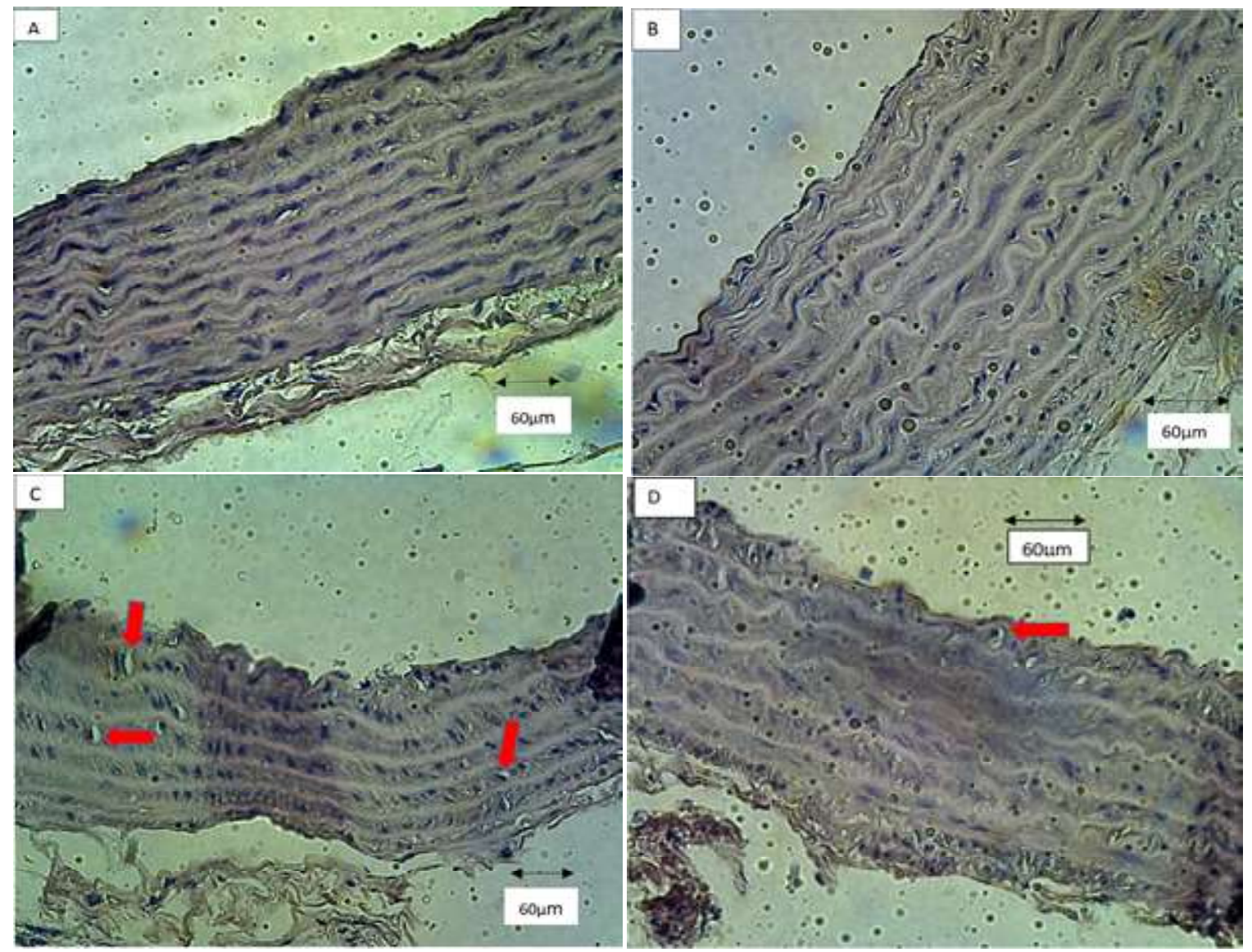

Figure 1. Photomicrographs of aortic arch cross sections of Wistar rats, HE staining, $40 \mathrm{x}$ magnification.

A: negative control group on standard feed AD II. B: positive control group on standard high fat diet. C: group T1 receiving shortening and standard feed $\mathrm{AD}$ II at the ratio of 1:5. D : group $\mathrm{T} 2$ receiving shortening and standard feed $\mathrm{AD}$ II at the ratio of 1:10.Red arrows: foam cells

\section{DISCUSSION}

The present study shows that the use of high fat feeds comprising a combination of shortening and standard feed at a ratio of either 1:5 or 1:10 did not yet show a significant increase in foam cell count. These results are in line with previous studies reporting that administraticn of high fat feeds in consisting of $0.2 \%$ egg yolk, $2 \%$ cholic acid, fat $5 \%$ goat and $92.8 \%$ standard feed in amounts of 20 gram/day was proved to be able to form foam cells but did not yet show a significant increase in foam cell count in the control group and the groups receiving the aforesaid high fat feeds. ${ }^{(17)}$ These results differ from those of a study on the administration of lard, which showed an increase in foam cell count. ${ }^{(10)}$ The differing results may very well be the result of a difference in the induction period of the test animals. In the latter study the induction period was 8 weeks, whereas in our study the induction period was 6 weeks. An induction period of less than 8 weeks may cause less than optimal foam cell formation. This is also referred to in the study of Nurmasitoh and Pramaningtyas (11) who found that administration of shortening for 14 days to Wistar rats already showed a significant increase in lipid profile. ${ }^{(11)}$ However, as a result of the shorter induction period, the increase in lipid profile could not yet lead to significant structural vascular changes, i.e. an increase in wall thickness and foam cell count.

Atherosclerosis occurs as a result of the conversion of low density lipoprotein (LDL) to oxidized LDL, causing endothelial lesions. Oxidized LDL and plasma molecules also undergo extravasation into the endothelial space where they are trapped so that they may become 

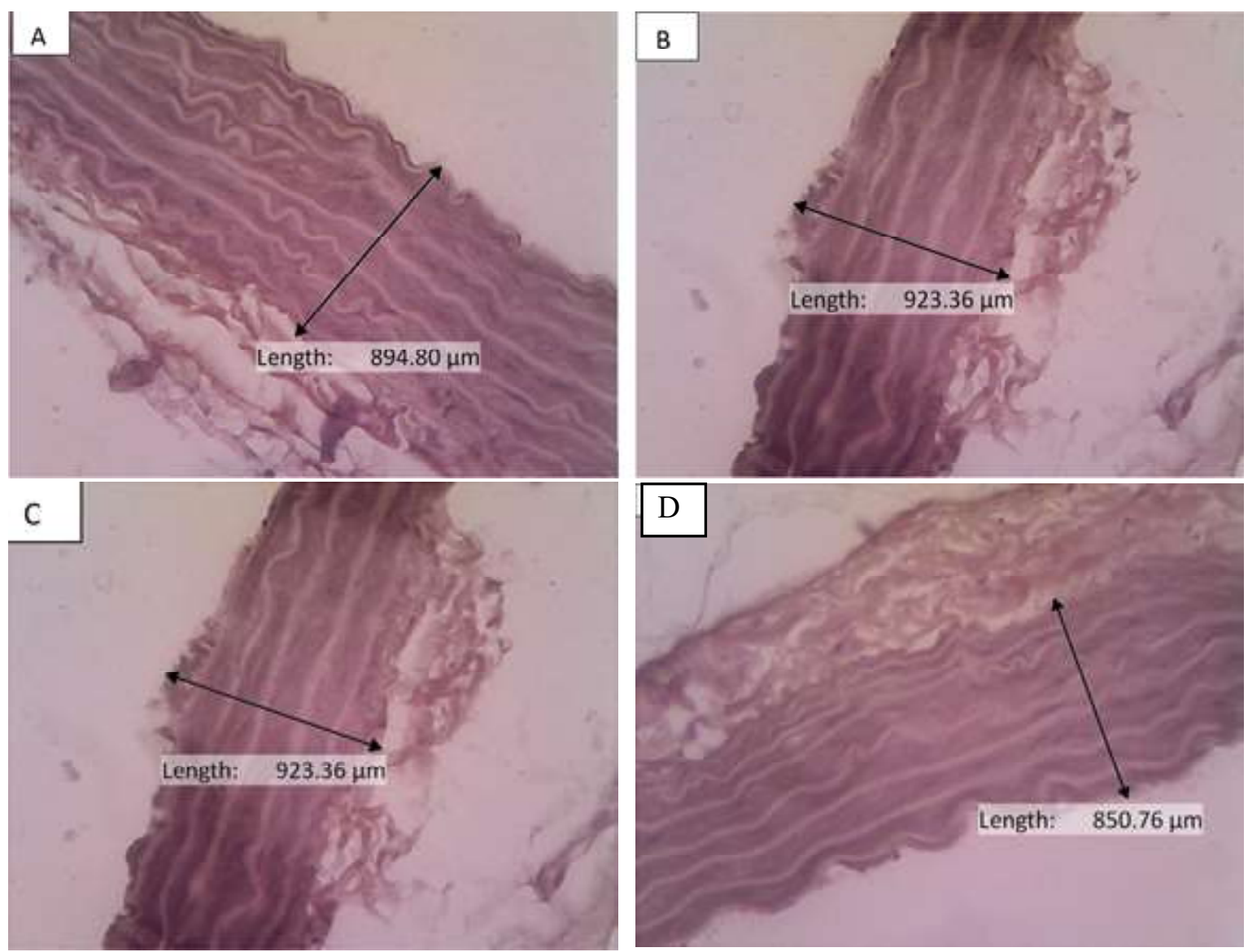

Figure 2. Photomicrographs of abdominal aorta cross sections of Wistar rats, HE staining, $\mathrm{Z}$ x magnification A: negative control group on standard feed AD II. B: positive control group on standard high fat diet.

C: group T1 receiving shortening and standard feed AD II at the ratio of 1:5. D : group T2 receiving shortening and standard feed $\mathrm{AD}$ II at the ratio of 1:10

cytotoxic, proinflammatory, chemotactic, and proatherogenic. Endothelial injury facilitates the entry of monocytes that adhere in the subendothelial space and subsequently become macrophages. Active macrophages will secrete an oxygen species toxin that increases LDL oxidation, leading to the development of foam cells. In addition, the endothelium becomes more active, with a decrease in NO synthesis and development of endothelial stiffness. ${ }^{(18,19)}$

Our study also showed that the use of a combination of shortening in standard feed at a ratio of 1:5 or 1: 10 also does not yet show an increase in vessel wall thickness. This supports the results of a previous study where administration of daun katuk (Sauropus androgynus or sweetleaf), cholic acid and cholesterol for 8 weeks, also did not have significant effects on vessel wall thickness. ${ }^{(20)}$
Another study also states that fat induction in Wistar rats significantly increases the lipid concentration in the $22^{\text {nd }}$ week. ${ }^{(21)}$

A limitation of the present study is the relatively short intervention period so that the results were less than maximal. Therefore there is a need for further studies using higher induction doses and longer intervention periods, so that the results will be according to theory.

\section{CONCLUSION}

Shortening tend to increase the aortic arch foam cell count and abdominal aortic wall thickness in male Wistar rats.

\section{CONFLICT OF INTEREST}

There was no conflict of interest. 


\section{ACKNOWLEDGEMENT}

We thank the UPPM, Faculty of Medicine Universitas Islam Indonesia for the funding of this study. We also express our utmost gratitude to Ernadita Budi Astuti, Fauzi Ahmad, Angkit Daru Prihatmoko for their technical assistance during the course of this study. Thanks are also due to all parties who contributed to the completion of this study.

\section{CONTRIBUTORS}

RL and MDP contributed to the design of the study and drafting of the manuscript. TN and RHD contributed to data collecting and analysis. AD contributed to revising the manuscript. All authors read and approved the final manuscript.

\section{REFERENCES}

1. Carmen G, Iliescu C. Modern risk stratification in coronary heart disease. J Med Life 2011;4:377-86.

2. Rohilla A, Dagar N, Rohilla S, et al. Hyperlipidemiaa deadly pathological condition. Int J Curr Pharm Res 2012;4: 15-8.

3. Finegold JA, Asaria P, Francis DP. Mortality from ischaemic heart disease by country, region, and age: Statistics from World Health Organisation and United Nations. Int J Cardiol 2013;168: 93445.

4. World Health Organization. Global status report on noncomunicable disease 2010. Geneva: World Health Organization; 2011.

5. Harikumar K, Althaf SA, Kishore KB, et al. A review on hyperlipidemic. Int J Nov Trends Pharm Sci 2013;3: 69-80.

6. Bonomini F, Rodella LF, Rezzani R. Metabolic syndrome, aging and involvement of oxidative stress. Aging Dis 2015;6:109-20. doi: 10.14336/ AD.2014.0305.

7. Csonka C, Sarkozy M, Pipicz M, et al. Modulation of hypercholesterolemia-induced oxidative/ nitrative stress in the heart. Oxid Med Cell Longev 2016;2016:1-23. doi: 10.1155/2016/3863726.

8. Alkhamees OA. Protective effects of Vitamin-P and Vitamin-C on hypercholesterolemia-induced oxidative hepatic damage and lipid profile changes in female rats: a comparative study. J Appl Pharm Sci 2013;3:99-105.

9. Dewi NCP, Probosari E. Pengaruh pemberian ekstrak kacang hijau (Phaseolus radiatus) terhadap kadar kolesterol LDL serum tikus hiperkolesterolemia. J Nutr Coll 2013;2:585-92.

10. Maramis R, Kaseke MK, Tanudjadja GN Gambaran histologi aorta tikus wistar dengan diet lemak babi setelah pemberian ekstrak daun sirsak (annona muricata). J e-Biomedik 2014;2:431-35.

11. Nurmasitoh T, Pramaningtyas MD. Honey improves lipid profile of diet-induced hypercholesterolemic rats. Univ Med 2015;34:17786. doi: 10.18051/UnivMed.2016.v35.177-186.

12. Mamat H, Hill SE. Effect of fat types on the structural and textural properties of dough and semi-sweet biscuit. J Food Sci Technol 2014;51:1998-2005.

13. Jissy Jacob, Leelavathi K. Effect of fat-type on cookie dough and cookie quality. J Food Eng 2007;79:299-305.

14. Tomkin GH, Owens D. LDL as a cause of atherosclerosis. Open Atherosclerosis Thromb J 2012;5:13-21.

15. Eckel RH, Borra S, Lichtenstein AH, et al. Understanding the complexity of trans fatty acid reduction in the American diet. Circulation 2007; 115:2231-46.

16. Dahlan S. Statistik untuk Kedokteran dan Kesehatan Edisi 6. Epidemiologi Indonesia. Jakarta; 2014.

17. Welinsa F, Asni E, Malik Z, et al. Histopatologi arteri torasika Rattus novergicus strain wistar jantan setelah 8 minggu pemberian diet aterogenik. JOM FK 2014;2:1-11.

18. Bentzon JF, Otsuka F, Virmani R, et al. Mechanisms of plaque formation and rupture. Circ Res 2014; 114;1852-1866. doi: 10.1161/CIRCRESAHA.114. 302721.

19. Porth CM, Grossman S, editors. Porth's pathophysiology concepts of altered health states. $9^{\text {th }}$ ed. Philadelphia: Wolters Kluwer Health: Lippincott Williams \& Wilkins; 2014.

20. Callisa O, Handayani D, Tritisari KP. Pengaruh pemberian tepung daun katuk terhadap penebalan dinding aorta tikus wistar. Indones $\mathrm{J}$ Human Nutr 2015;2:85-90.

21. Heriansyah T. Pengaruh berbagai durasi pemberian diet tinggi lemak terhadap profil lipid tikus putih (Rattus norvegicus strain Wistar) jantan. J Kedokt Syah Kuala 2013;13:114-50. 